\title{
SATISFACTION WITH E-LEARNING QUALITY EXPRESSES READINESS TO DEVELOP OWN ONLINE COURSE, NOT ONLY JUST TO FURTHER STUDY ONLINE
}

\author{
Lambri Yovkov \\ Plovdiv University "Paisii Hilendarski", Bulgaria \\ E-mail: I_yovkov@abv.bg \\ Stanislava Stoyanova \\ South-West University "Neofit Rilski", Bulgaria \\ E-mail: avka@abv.bg
}

\begin{abstract}
E-learning has become an important part of contemporary educational process. Satisfaction with e-learning quality was studied among 133 Bulgarian participants in an online survey, of which more than the half took part is some e-learning courses. The results indicated that the learners for whom e-learning was a part of their education at school or university tended to do more online courses and were more satisfied with e-learning quality, so traditional education seemed to support e-learning. The participants who had been enrolled in some online courses, who had their own Internet site and who were satisfied with e-learning quality were more self-confident in their ability of developing an online course. Satisfaction with e-learning prevailed in the sample, because approximately one out of ten participants stated firmly not being satisfied with e-learning quality and four out of five participants would like to use e-learning as a part of their further education. More male participants were satisfied with e-leaning quality than the female participants in support of some previous findings concerning higher life satisfaction in men than in women. Satisfaction with e-learning could be considered as a domain-specific satisfaction that is a part of overall life satisfaction.
\end{abstract}

Keywords: gender differences in satisfaction, e-learning quality, satisfaction with e-learning.

\section{Introduction}

It is important to study satisfaction with e-learning, because e-learning not only complements traditional learning, but more and more often has become an independent form of contemporary education. Satisfaction is based on a total cognitive estimation of the whole life (Diener, Emmons, Larsen, \& Griffin, 1985, p.71; Diener \& Seligman, 2018, p.172; Emmons \& Diener, 1985, p.89; Kesebir \& Diener, 2008, p.118; van Beuningen, 2012, p.5) or of some aspect of own life (Kesebir \& Diener, 2008, p.118; van Beuningen, 2012, p.5) related to the achievements and way of living (Ivanova, 2014, p.21). Satisfaction results from a long-term estimation of own life (Ivanova, 2014, p.13; Keyes, Shmotkin, \& Ryff, 2002, p.1007) or of some aspect of own life. Satisfaction is a positive evaluation of some conditions, qualities, aspects compared with some standards and expectations 
(Prasoon \& Chaturvedi, 2016, p. 26, p. 28), according to some selected criteria (Diener et al., 1985).

It has been found that Bulgarians below 20 years old are satisfied with their life (Ivanova, 2014, p.30) that suggests that the students should be satisfied with their learning, including e-learning. There is a trend the students in Bulgaria to be more satisfied with their life in recent years compared to past years (Garvanova, 2011, p.77) that gives some reasons to conclude that higher students' satisfaction may be related to higher deal of e-learning in contemporary education.

It has been established that higher educational level is related to higher life satisfaction as an expression of well-being (Diener \& Ryan, 2009, p. 397; Keyes, Shmotkin, \& Ryff, 2002, p. 1007). It has been found that students are satisfied with their life (Pavot \& Diener, 2015, p. 142). That is why it is expected that previous e-learning experience and participation in more online courses would be related to higher satisfaction with e-learning quality. Participation in more online courses expresses both the interest in e-learning and satisfaction with this kind of learning.

\section{Hypotheses}

It was supposed that previous e-learning experience and participation in more online courses would be related with higher satisfaction with e-learning quality and further plans to study online. It was supposed that satisfaction with e-learning quality would be related to further plans to study online.

It was supposed that previous experience with e-learning as a part of institutional education at school or university would be related to higher satisfaction with e-learning quality and further plans to study online, because the authority of institutional education would support e-learning.

It was supposed that people would be more self-confident that they would be able to develop their own online course if they already possessed an Internet site and they had some previous experience with e-learning as being participants in some online courses.

Some findings reveal higher life satisfaction in men than in women (Zuckerman, Li, \& Diener, 2017, p. 329), including in Bulgaria (Papazova, 2010, p. 101) that is why gender differences were expected in satisfaction with e-learning.

\section{Research Methodology}

\section{Research Background}

The exploratory research tried to understand the degree of satisfaction with e-learning quality and some factors that may contribute to it - such as previous experience with e-learning, the number of the online courses that were done, e-learning as being part of traditional institutional education, possession of own Internet site, and some social-demographic differences. This investigation was conducted to determine if satisfaction with e-learning just involved further plans to study online or stimulated own creative development of an online course. A cross-sectional quantitative study was conducted online from February to May 2019 comparing some groups of participants divided by their answers to the questions in the survey.

\section{Sample and Procedure}

The sample consisted of 133 participants who studied by means of an online survey in Bulgarian through Google forms in 2019. They were recruited among the students and the workers. They participated voluntarily. Online form of conducting the study was selected as more relevant to e-learning.

The female participants $(N=76,57.1 \%)$ were more than the male participants $(N=56,42.1 \%)$ and one participant did not indicate his/her gender belonging $(0.8 \%)$. Younger participants between 18-30 years old $(N=82,61.7 \%)$ prevailed than the older participants between 31-67 years old $(N=51,38.3 \%)$. 


\section{Instrument}

The survey comprised several questions. The indicators of experience with e-learning were the questions - "How many online courses have you been enrolled in?" ( $0 ; 1-3$; more than 3$)$, and "Have you used e-learning as a part of your education at school or university?" (No; Yes). Further plans related to e-learning were studied by means of the indicators of ability to develop an online course - "Do you consider that you can develop an e-learning course?" (No; Yes), and "Do you have your own Internet site?" (No; Yes), as well as by the question "Do you want to use e-learning as a part of your further education?" (No; I do not know; Yes). The indicators of satisfaction with e-learning were the questions - "Do you want to use e-learning as a part of your further education?" (No; I do not know; Yes), and "Are you satisfied with e-learning quality?" (No; I do not know; Yes).

\section{Data Analysis}

Data were processed statistically by means of SPSS 20 using descriptive statistics and chi-square analysis with Phi measure of effect size. Only the statistically significant coefficients are reported.

\section{Research Results}

Most participants took part in some e-learning courses $(N=72,54.1 \%)$ and 46 of them studied up to three online courses, while 26 of them studied more than three online courses. Less than half of the participants did not study any online course $(N=61,45.9 \%)$.

Most participants did not use e-learning as a part of their education at school or university $(N=73,54.9 \%)$. Almost every third participant used e-learning as a part of their education at school or university $(N=60,45.1 \%)$.

If the participants had some experience with e-learning as a part of their education at school or university they tended to do more online courses than if e-learning was not a part of their institutional education (see Table $1, \chi^{2}(N=133, d f=2)=49.118, p<.001$, Phi $\left.=0.608\right)$.

\section{Table 1. Comparison of using e-learning as a part of education at school or university with the number of online courses in which the participants were enrolled.}

\begin{tabular}{|c|c|c|c|c|c|}
\hline & & & \multicolumn{3}{|c|}{$\begin{array}{c}\text { Frequencies of the answers to "How many online } \\
\text { courses have you been enrolled in?" }\end{array}$} \\
\hline & & & 0 & $1-3$ & $>3$ \\
\hline \multirow{4}{*}{$\begin{array}{l}\text { Frequencies of the } \\
\text { answers to "Have you } \\
\text { used e-learning as a } \\
\text { part of your education at } \\
\text { school or university?" }\end{array}$} & \multirow{2}{*}{ No } & Empirical count & 53 & 16 & 4 \\
\hline & & Expected count & 33.5 & 25.2 & 14.3 \\
\hline & \multirow{2}{*}{ Yes } & Empirical count & 8 & 30 & 22 \\
\hline & & Expected count & 27.5 & 20.8 & 11.7 \\
\hline
\end{tabular}

Most participants hesitated if they were satisfied with e-learning quality $(N=62,46.6 \%)$ or stated firmly that they were satisfied with e-learning quality $(N=60,45.1 \%)$. A small number of participants declared that they were not satisfied with e-learning quality $(N=11,8.3 \%)$.

The participants who had some experience with e-learning as a part of their education at school or university seemed to be more satisfied with e-learning quality than the participants who did not have any experience with e-learning as a part of their education at school or university (see Table 2, $\chi^{2}(N=133, d f=2)=12.240, p=.002$, Phi $\left.=0.303\right)$. 
Frequencies of the answers to "Are you satisfied with e-learning quality?"

\begin{tabular}{|c|c|c|c|c|c|}
\hline & & & No & $\begin{array}{l}\text { I do not } \\
\text { know }\end{array}$ & Yes \\
\hline \multirow{4}{*}{$\begin{array}{l}\text { Frequencies of the answers } \\
\text { to "Have you used e-learning } \\
\text { as a part of your education at } \\
\text { school or university?" }\end{array}$} & \multirow{2}{*}{ No } & Empirical count & 5 & 44 & 24 \\
\hline & & Expected count & 6.0 & 34.0 & 32.9 \\
\hline & \multirow{2}{*}{ Yes } & Empirical count & 6 & 18 & 36 \\
\hline & & Expected count & 5.0 & 28.0 & 27.1 \\
\hline
\end{tabular}

More than a half of the participants considered that they were not able to develop an e-learning course $(N=78,58.6 \%)$, but some participants declared that they could develop an e-learning course $(N=55,41.4 \%)$.

The participants who were enrolled in some online courses more often considered that they could develop an online course than the participants who did not study any online course (see Table 3, $\chi^{2}(N=133, d f=2)=18.207, p<.001$, Phi $\left.=0.370\right)$.

Table 3. Comparison between the number of online courses being enrolled in and the ability for developing an online course.

\begin{tabular}{|c|c|c|c|c|}
\hline & & & \multicolumn{2}{|c|}{$\begin{array}{l}\text { Frequencies of the answers to "Do you consider } \\
\text { that you can develop an e-learning course?" }\end{array}$} \\
\hline & & & No & Yes \\
\hline \multirow{6}{*}{$\begin{array}{l}\text { Frequencies of the answers } \\
\text { to "How many online courses } \\
\text { have you been enrolled in?" }\end{array}$} & \multirow{2}{*}{0} & Empirical count & 46 & 15 \\
\hline & & Expected count & 35.8 & 25.2 \\
\hline & \multirow{2}{*}{$1-3$} & Empirical count & 25 & 21 \\
\hline & & Expected count & 27.0 & 19.0 \\
\hline & \multirow{2}{*}{$>3$} & Empirical count & 7 & 19 \\
\hline & & Expected count & 15.2 & 10.8 \\
\hline
\end{tabular}

Most participants did not have their own Internet site $(N=110,82.7 \%)$. Almost one out of six participants had his/her own Internet site $(N=23,17.3 \%)$.

The participants who had their own Internet site more often considered that they could develop an online course than the participants who did not have their own Internet site (see Table 4, $\left.\chi^{2}(N=133, d f=1)=9.126, p=.003, \mathrm{Phi}=0.262\right)$.

Table 4. Comparison between possession of own Internet site and the estimated own ability for developing an online course.

\begin{tabular}{|c|c|c|c|c|}
\hline & & & \multicolumn{2}{|c|}{$\begin{array}{l}\text { Frequencies of the answers to "Do you consider } \\
\text { that you can develop an e-learning course?" }\end{array}$} \\
\hline & & & No & Yes \\
\hline \multirow{4}{*}{$\begin{array}{l}\text { Frequencies of the answers } \\
\text { to "Do you have your own } \\
\text { Internet site?" }\end{array}$} & \multirow{2}{*}{ No } & Empirical count & 71 & 39 \\
\hline & & Expected count & 64.5 & 45.5 \\
\hline & \multirow{2}{*}{ Yes } & Empirical count & 7 & 16 \\
\hline & & Expected count & 13.5 & 9.5 \\
\hline
\end{tabular}


The participants who hesitated if they were satisfied with e-learning quality more often considered that they could not develop an online course than the participants who were sure about their satisfaction with e-learning quality (see Table $5, \chi^{2}(N=133, d f=2)=11.576, p=.003$, Phi $=$ 0.295). The participants who were satisfied with e-learning quality more often considered that they could develop an e-learning course than the participants who were not satisfied with e-learning quality and particularly the participants who hesitated if they were satisfied with e-learning quality (see Table 5).

Table 5. Comparison between satisfaction with e-learning quality and the estimated own ability for developing an online course.

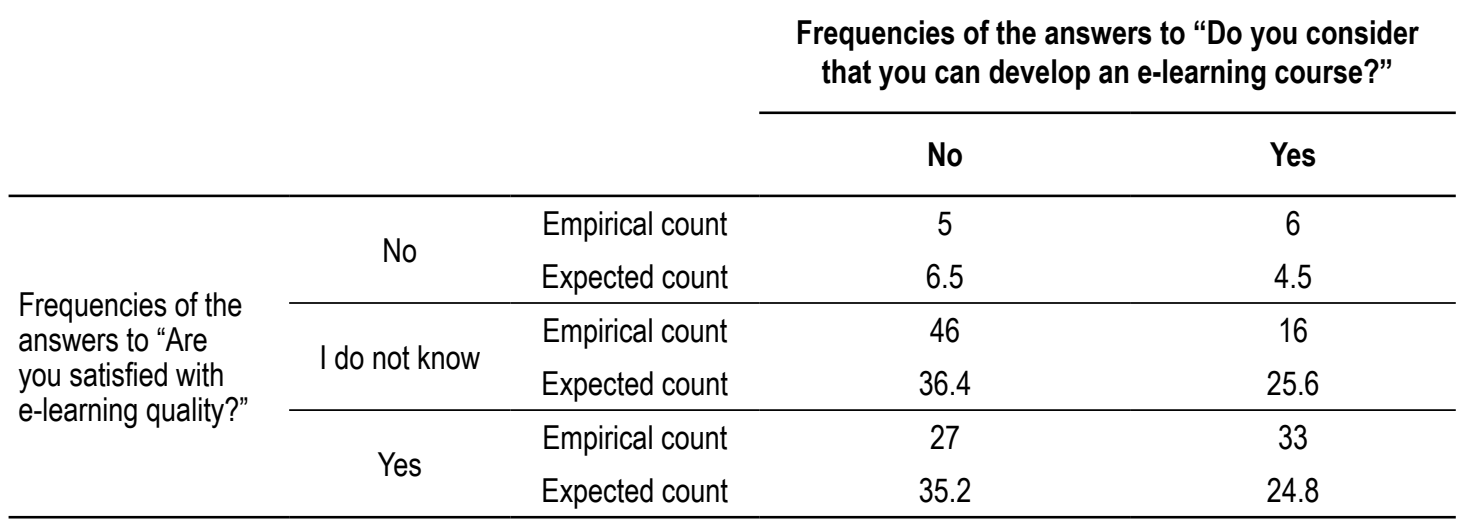

Four out of five participants $(N=108,81.2 \%)$ would like to use e-learning as a part of their further education. The other participants hesitated $(N=22,16.5 \%)$ or did not want to use e-learning as a part of their further education $(N=3,2.3 \%)$.

Table 6. Gender differences in satisfaction with e-learning quality.

\begin{tabular}{|c|c|c|c|c|c|}
\hline & & & \multicolumn{3}{|c|}{$\begin{array}{c}\text { Frequencies of the answers to "Are you satisfied with } \\
\text { e-learning quality?" }\end{array}$} \\
\hline & & & No & I do not know & Yes \\
\hline \multirow{4}{*}{$\begin{array}{l}\text { Gender } \\
\text { belonging }\end{array}$} & \multirow{2}{*}{ Men } & Empirical count & 5 & 15 & 36 \\
\hline & & Expected count & 4.7 & 25.9 & 25.5 \\
\hline & \multirow{2}{*}{ Women } & Empirical count & 6 & 46 & 24 \\
\hline & & Expected count & 6.3 & 35.1 & 34.5 \\
\hline
\end{tabular}

More male participants were satisfied with e-leaning quality than the female participants (see Table $6, \chi^{2}(N=132, d f=2)=15.572, p<.001$, Phi $\left.=0.343\right)$. More female participants hesitated if they were satisfied with e-leaning quality than the male participants (see Table 6).

Table 7. Age differences in use of e-learning as a part of education at school or at university.

\begin{tabular}{|c|c|c|c|c|}
\hline & & & \multicolumn{2}{|c|}{$\begin{array}{l}\text { Frequencies of the answers to "Have you used e-learning } \\
\text { as a part of your education at school or university?" }\end{array}$} \\
\hline & & & No & Yes \\
\hline \multirow{4}{*}{ Age groups } & \multirow{2}{*}{$18-30$ years old } & Empirical count & 36 & 46 \\
\hline & & Expected count & 45.0 & 37.0 \\
\hline & \multirow[t]{2}{*}{ 31-67 years old } & Empirical count & 37 & 14 \\
\hline & & Expected count & 28.0 & 23.0 \\
\hline
\end{tabular}


More younger participants used e-leaning as a part of their institutional education at school or university than the older participants (see Table $7, \chi^{2}(N=133, d f=1)=10.421, p=.001$, Phi $=$ $0.280)$. Traditional education in recent years relies more on e-learning than in the past.

\section{Discussion}

It has been found that previous e-learning experience was related to higher satisfaction with e-learning quality and readiness to be developed an own online course instead of only further plans to study online that expresses the interest in e-learning. The small number of students who were not satisfied with e-learning (approximately one student out of ten) supported the overall students' life satisfaction found by Pavot and Diener (2015). E-learning uses diverse means for presentation of learning content - text, image, sound, required activity, so the different learners' preferences are satisfied. The learners who consider themselves as efficacious and coping well use Internet more than the learners who are not satisfied with their learning achievements (Poude, Zamani, \& Abedi, 2011, p.2694) that also reveals the connection between e-learning and satisfaction with online learning.

It has been found that previous experience with e-learning as a part of institutional education at school or university was related to doing more online courses and higher satisfaction with e-learning quality. It seems that the authority of institutional education supports e-learning.

It has been found that satisfaction with e-learning quality was related to self-confidence in own ability to develop an e-learning course instead of just further plans to study online. It has been established that people would be more self-confident that they would be able to develop their own online course if they already possessed an Internet site and if they had some previous experience with e-learning as participants in some online courses.

Gender differences were found in satisfaction with e-learning such that more male participants were satisfied with e-leaning quality than the female participants and more female participants hesitated if they were satisfied with e-leaning quality than the male participants. These results supported some previous findings concerning higher life satisfaction in men than in women (Zuckerman, Li, \& Diener, 2017, p. 329), including in Bulgaria (Papazova, 2010, p. 101).

This study had some limitations concerning the number of participants who were enrolled in online courses, using only self-report measurement and only one measure - an online survey, relying on honesty of given anonymous answers, comparing the answers of different questions permitted in some degree to establish if the participants responded sincerely. Anonymity of answering reduced social desirability.

\section{Conclusions}

This study contributes to scientific knowledge with revealing the overall high students' satisfaction with e-learning and some of its consequences as increasement of self-confidence of being able to become an active and leading part of the learning process with the readiness to develop an own online course after previous experience with e-learning and management of own Internet site. It has been found that satisfaction with e-learning quality expresses readiness to develop own online course instead of just to further study online.

Future studies could focus on more social-demographic factors contributing to satisfaction with e-learning, not only on gender differences. Satisfaction with e-learning might be measured in different scientific areas.

\section{References}

Diener, E., Emmons, R., Larsen, R., \& Griffin, S. (1985). The Satisfaction with Life Scale. Journal of Personality Assessment, 49(1), 71-75.

Diener, E., \& Ryan, K. (2009). Subjective well-being: A general overview. South African Journal of Psychology, 39(4), 391-406. https://doi.org/10.1177/008124630903900402. 
OF PSYCHOLOGY

IN THE $21^{\text {st }}$ CENTURY Vol. 13, No. 1, 2019

Diener, E., \& Seligman, M. E. P. (2018). Beyond money: Progress on an economy of well-being. Perspectives on Psychological Science, 13(2), 171-175. https://doi.org/10.1177/1745691616689467.

Emmons, R. A., \& Diener, E. (1985). Personality correlates of subjective well-being. Personality and Social Psychology Bulletin, 11(1), 89-97. https://doi.org/10.1177/0146167285111008.

Garvanova, M. (2011). Osnovni zhizneni celi, udovletvorenost ot zhivota i cennostna kriza pri balgarski studenti (sravnitelen podhod) [Main life goals, life satisfaction and value crisis in bulgarian students (Comparative approach)]. Balgarsko spisanie po psihologia, 38(3-4), 77-84.

Ivanova, E. A. (2014). Vzaimovrazki mezhdu internet zavisimost, kiberhondriya i blagopoluchie. Avtoreferat na disertatsiya za prisazhdane na obrazovatelna i nauchna stepen ,Doktor” [Interconections between Internet dependence, cyberhondria and well-being. PhD thesis abstract]. Sofiya: SU "Sv. Kliment Ohridski".

Kesebir, P., \& Diener, E. (2008). In pursuit of happiness: Empirical answers to philosophical questions. Perspectives on Psychological Science, 3(2), 117-125. https://doi.org/10.1111/j.1745-6916.2008.00069.x.

Keyes, C. L. M., Shmotkin, D., \& Ryff, C. D. (2002). Optimizing well-being: The empirical encounter of two traditions. Journal of Personality and Social Psychology, 82(6), 1007-1022. https://doi.org/10.1037//00223514.82.6.1007.

Papazova, E. (2010). Determinants of gender-role attitudes, self-esteem and affective balance at adolescence. Psihologichni izsledvania, 13(2), 101-106.

Pavot, W., \& Diener, E. (2015). The Satisfaction With Life Scale and the emerging construct of life satisfaction. Journal of Positive Psychology, 3(2), 137-152. doi: 10.1080/17439760701756946.

Prasoon, R., \& Chaturvedi, K. R. (2016). Life satisfaction : A literature review. The Researcher - International Journal of Management Humanities and Social Sciences, 1(2), 25-32.

Poude, L. D., Zamani, B. E., \& Abedi, A. (2011). Relation between Iranian students' attitudes subscales with the kind of internet usage in universities. Procedia - Social and Behavioral Sciences, 15, 2694-2698. https://doi.org/10.1016/j.sbspro.2011.04.172.

van Beuningen, J. (2012). The statisfaction with life scale examining construct validity. Discussion Paper (201209). The Hague: Statistics Netherlands.

Zuckerman, M., Li, C., \& Diener, E. F. (2017). Societal conditions and the gender difference in well-being: Testing a three-stage model. Personality and Social Psychology Bulletin, 43(3), 329-336. https://oi. org/10.1177/0146167216684133.

Received: March 28, 2019

Accepted: June 21, 2019

Lambri Yovkov PhD Student at Plovdiv University "Paisii Hilendarski", 24 Tzar Assen Street,

Plovdiv, Bulgaria.

E-mail: I_yovkov@abv.bg 